\title{
Globalization and localization in advertising translation: a love-hate relationship?
}

\author{
Cristina Valdés Rodríguez ${ }^{1}$
}

University of Oviedo

\begin{abstract}
The aim of this paper is to analyse how globalization has affected the activity of advertising translation, paying heed to how globalization and localization approaches integrate translation as a strategy to promote different kinds of products and in different media. A theoretical introduction will be provided on the intercultural and interdisciplinary nature of advertising and more precisely of advertising translation, also dealing with notions like institutional norms or with the well-known expression "Think globally, act locally". Recent examples from printed campaigns, television spots and promotional material from several websites will be analysed to show how translation reveals the contradictions and principles inherent to globalization, and the tensions, or lack of them, between globalising and localising strategies, trying to reveal signs of homogenisation of cultural beliefs, customs and images, through the detailed analysis of a global product being promoted in local markets, and of a local brand aiming at becoming international.
\end{abstract}

Keywords: globalization, localization, advertising translation, homogenisation

\section{RESUMEN}

En este artículo se pretende analizar cómo la globalización ha influido en la actividad traductora del material publicitario, prestando especial atención a la forma en que los

Corresponding author - University of Oviedo, Department of English, French and German Philology, Facultad de Filosofía y Letras, Calle del Teniente Alfonso Martínez, 33011 Oviedo, Asturias (España).

Email: cris@uniovi.es 
enfoques globalizadores y localizadores han integrado la traducción como una estrategia para promocionar distintos tipos de productos en diferentes medios de comunicación. Se realizará una introducción teórica a la naturaleza interdisciplinar e intercultural de la publicidad y más concretamente de la traducción publicitaria, haciendo hincapié en conceptos como el de norma institucional o en la conocida expresión "Piensa globalmente, actúa localmente". El análisis textual se realizará a partir de campañas en prensa, de anuncios de televisión y de material promocional extraído de diversas páginas web, cuya traducción nos revelará las contradicciones y los principios inherentes a la globalización, y las tensiones, o la falta de ellas, entre las estrategias globalizantes y localizadoras. Este análisis detallado de un producto global que se promociona en mercados locales y de una marca local que trata de convertirse en internacional permite descubrir algunos indicios de la homogeneización de las creencias, costumbres e imágenes asociadas a una cultura concreta.

Palabras clave: globalización, localización, traducción, publicidad, homogeneización

\section{Introduction}

This theoretical reflection is based on the assumption that advertising translation is an act or process of intercultural communication (Valdés, 2004) whose study demands an adequate theoretical framework and an interdisciplinary approach. Therefore, this area of research requires the inclusion of concepts and methodologies from other subject areas and professional backgrounds in order to fully comprehend all the current variations and challenges in advertising. Some of the disciplines that contribute to providing a thorough view of what is happening today about international advertising and advertising translation range from Text Linguistics to Audience Design, including Marketing, Visual Semiotics, Discourse Analysis, Communication or Reception Studies, among others. All these disciplines throw different lights to the study of advertising translation, where prime concepts in both research and practice are "culture" and "communication". Authors such as Gideon Toury (1995), Hans Vermeer $(1989,1992)$ or Mary Snell-Hornby (1988) were pioneers of the cultural turn in Translation Studies towards a conception of translation as an act of intercultural communication and as a process of cultural transfer, specifying that this transcultural act always fulfils a particular function and takes place under certain circumstances and conditions. Moreover, the shift from a notion of culture based on writing and reading processes towards a cultural model characterised by the predominance of audiovisual and multimedia texts, which combine advanced and sophisticated systems of communication, has given rise to other research interests such as screen translation or advertising communication. Issues such as the invisibility of the translator, or translation as both linguistic and ideological manipulation are also at stake when focusing on advertising translation.

The study of advertising translation, and of translations in general, adopts a wider 
sociocultural approach, acquiring a double dimension when analysing the texts. On the one hand, questions about the translation strategies that lie behind the process are formulated, and on the other hand, the effects of sociocultural and political circumstances on these translation strategies are considered, particularly concerning their impact on the production and the reception of the target texts. Back to 1994, an initial hypothesis about the importance of more 'external' norms was presented by Lambert (1994, p. 23-24), with reference to the fact that translations and translation models are part of more general cultural and social models:

[N]early everything has to be done/investigated about the "external" norms -i.e. the norms that are not specific to translation but rather to more general communicational principles - and in particular the institutional norms. Since they are supposed to refer to collective behaviour and attitudes rather than to individual/idiosyncratic ones, the first kind of norms we have to take into consideration as scholars are the public and institutional ones.

Therefore, as Lambert indicates, in order to better understand the translation strategies, it is necessary to locate the text within a wider macrostructure so that the function of the target text and the institutional norms can be defined. This set of norms is applicable over a broad range of textual types, especially those of a more public character, like advertising or promotional texts, as advertising occupies a prominent position in international communication and economic transactions, while conveying cultural nuances and meanings. Consequently, in the twenty-first century, a first hypothesis claims that to study and to understand advertising translation naturally involves studying and understanding the tensions between a global and a local approach to culture, since there are different institutional norms, namely marketing ones, which result in decisions involving translation and crosscultural communication. In the next few sections we will illustrate this hypothesis by paying attention to the cline between globalization and localization in advertising and to the different concepts, products, values and languages present in advertising translation processes. Examples have been selected for their representativeness of trends, although there are only a few being analysed in the paper, and this choice has been made after the observation of promotional texts of different kind. Therefore, the methodology has mainly consisted of the textual and contextual description of the texts to finally draw some preliminary conclusions, which should be surely complemented with further studies of a broader corpus of texts. 


\section{Globalization and localization, and the challenges to translation}

The principle of globalization, born in the field of economy decades ago (Levitt, 1983), is applied in general terms to the organisation of economies and the organisation of advertising activities, which is in the hands of a few multinational communication agencies. This concentration partly contributes to the spreading of similar ideas and values through advertising. Similarly, in recent decades mass media have formed a few global networks to better control the market. It seems difficult then to escape from the cultural patterns that a few decide for the rest of us. In general, we can claim that music, images and words that constitute the advertisement cross borders, so that the product is associated with the same features in different cultures. The question is whether this is really so, given that conceiving the world as a "flat earth" (Cronin, 2013, p. 16) is far from being a straightforward notion. The original anxiety to export and expand the values and products of the dominant cultures, that is, the ideologies and traditions of a few, has grown into a balancing act towards struggling between economic efficiency and cultural success. Thus, the well-known motto "Think globally, act locally" entails translation as a crucial instrument to make global messages local.

The figure of a linguistic and cultural mediator, e.g. a translator, becomes a transmitter and communicator of advertising messages, which plays an active role during marketing transactions (Fuentes Luque \& Kelly, 2000). As Séguinot (1995, p. 56) remarked on the responsibility of translators, "Translators are implicitly expected to understand the requirements of different markets, and this means that translators need to understand the cultures towards which they are translating and in addition the basics of marketing". She pointed out some of the main challenges that globalization was bringing to translation (1995, p. 55):

\footnotetext{
Globalization of the translation business sometimes means providing full marketing services in addition to translation and interpreting. Therefore, in the marketing of goods and services across cultural boundaries, an understanding of culture and semiotics that goes well beyond both language and design is involved. Translators need to understand the basics of marketing; they need to know how cultural differences affect marketing; they must be aware of constraints placed by the form and functions of the source text, and they must be able to interpret the visual elements which are of key importance in advertising.
}

This passage clarifies the need for translators to go well beyond the words and to face the new demands of marketing, such as to understand the cultural and semiotic dimensions of texts, the cultural differences between markets, the importance of constraints imposed by the source text and the interpretation of the non-verbal component of advertisements. Some of these issues are object of study 
in previous publications focusing on advertising translation, such as Adab \& Valdés, 2004; Bueno García, 2000; Cómitre, 2000; Corpas et al., 2002; Cruz García, 2001; Dávila-Montes, 2008; Fernández Montes, 2016; Guidère, 2000; Lorenzo \& Pereira, 2005; Pedro Ricoy, 2007a and 2007b; Torresi, 2007 and 2010; and Valdés 2004.

At an international level, for economic and operational reasons, globalization also affects the production and the distribution of promotional texts, given that advertising texts are produced almost simultaneously for an international market and they are designed to appeal consumers from a variety of cultures. Once the decisions about the marketing campaign are made and its design is completed, the different textual material is tailored to suit several kinds of media, currently being television and the Internet the most widely used, given their effectiveness in terms of scope. Meanings and messages are likewise conceived globally, that is, aimed at a worldwide population, but adapted to the diverse local communities. The impact of the Web in particular has brought about a high, and rapid, demand of languagerelated interventions, as Anobile (2000) claimed (in Sprung, 2000, p. vii):

Ever more companies are beginning to understand the complexity and commitment behind going global which permeates every facet of an organization's structure. This includes language-investment strategies, language-processing technologies, translation systems, quality-assurance guidelines, and market education. The Web is only accelerating the trend.

Indeed the latest data about the number of Internet users confirm the potential convenience of selecting the Web as a medium for promotion, as user rates have been growing since its launching date ${ }^{2}$. Some of the questions that arise when localising global content to the maximum number of markets and consumers/users are related to language and culture-bound material, which maybe indispensable components of the advertising/promotional campaign and at the same time difficult to localize (Valdés, 2008). In this sense, the Localization Industry Standards Association (LISA), before shutting down operations, published its Localization Industry Primer in 2003 and its Globalization Industry Primer in 2007, where basic assumptions are made about how globalization and localization facilitate advertising activities, and about how translation is part of the localization project. Therefore, both the global and local approaches are complementary to overcome language and culture barriers that remain in a global world that has removed geographical barriers to trade and communication.

One of the questions at stake is about whether to employ a lingua franca, which may seem convenient for practical reasons, and about whether English is such global 
language, in consonance with the notion of a reduced standardised form of International English, so-called the "McLanguage" of the globalized "McWorld", or the "Eurospeak" of a multilingual continent", described by Snell-Hornby (2000). In the case of advertising, within agencies worldwide at the moment, it is undeniable that English is the common language for presentations of campaigns and for internal documentation, since most of these companies work under international partnership. The verbal component of the advertisement, either in its draft or final version, is usually written in English as well when it is an international campaign. Therefore, this first version could be translated into the language of the culture the advertisement is addressed to, or be left untranslated and marketed elsewhere by means of the same text.

In this sense, broad descriptions of the localization process can be used to account for this translation process in the field of advertising. Dollerup (2008, p. 41) illustrates a similar text production process within the sphere of localization in the following terms: "The general idea in localization is thus that a culturally indefinable source text, which may also consist of simplified language to allow easier translation ('controlled language'), is adapted to local languages and audiences". Since such 'deculturised' and 'controlled' texts are normally made only in industry and are considered trade secrets, it is hard to come up with authentic examples. In addition, they are usually translated into English as early in the process as possible, since English is the universal lingua franca today.

As Levitt pointed out in The Wall Street Journal in 1992, "The challenge is to effectively come up with ways to communicate the same message to a homogenised audience all over the world" (in Goldman, 1992, cited in Wells et al., 1995, p. 744). But is there such "homogenised audience" that makes it possible to employ a lingua franca? This notion of exploiting a lingua franca for communication purposes leads us to the issue of translation, since the choice of one language for the same advertisement in different cultures constitutes a strategy of non-translation. It is interesting to note that the preliminary decisions about the translation of the text are part of the marketing and communication campaign. As the detailed study of a wide corpus of advertisements has pointed out (Valdés, 2004), one of the earlier decisions in the processes focuses on the choice between translating or not the verbal component (or part of it) of the advertisement when this is launched in different countries. Some questions arise in relation to this: Is one language the lingua franca for different types of advertisements? Is it the same in all countries? Is the use of English as the international language in advertising a sign of the social and economic powers that lay behind globalization?

Once the preliminary norm about the language choice is decided, if the text is going to be transferred to a different culture, all textual elements, verbal and non-verbal, 
might entail certain transformations so as to convey the persuasive meaning of the advertisement. The examples analysed below show that the translation strategies depend to a high degree on whether the text is intended for different cultural groups but with a similar approach, and thus with none or minimum changes, or whether it can be transformed to accommodate it to the expectations of the target market. In the next sections, some considerations will be made about the effects of globalization and localization on the translation and communication strategies in advertising.

\section{Think globally, act locally}

The tensions between the principles of globalization and localization in advertising have converged into the more recent 'Think globally, act locally', which encapsulates the agreement between both positions. The following examples will show some advertisements from Spanish televisions and magazines as well as promotional websites in order to explore how globalization has had an impact on advertising and how translation plays a role as a cultural mediation/transmission process, with particular attention to the Spanish target culture. When translating advertising texts, not only the verbal but also the non-verbal elements are subject to change according to the degree of standardisation or adaptation to the target culture. In order to discuss these aspects, as we have already mentioned above, it is fundamental to take into account the inter-disciplinary nature of any research on translation, as this is crucial to understand the complex relationship between the text and its context and the interplay of the textual elements, and the role the digital age has played in advertising. Technologies have had a direct effect on the design, and thus on the translation, of advertisements, which are deliberately manipulated to be conveyed through several types of medium. Moreover, the global nature of the advertising campaign sometimes makes it difficult to associate the product, the concepts and the images implicit in the text with a particular culture. On the contrary, the homogenisation of images and texts tends to give shape to an internationally-perceived common culture, due to the so-often object-of-criticism “homogenisation" process.

However, the global and local tensions are mostly perceived in advertisements where the marketing strategy has triggered off the non-translation of the textual material and the homogenisation of images and values associated with it. For example, the campaigns for Absolut Vodka are run everywhere based on a wellknown series of advertisements which feature the bottle of vodka in the centre of the image. As part of a global strategy, the adverts often play on the relationship between the slogan and the pictures, and verbal messages are presented in English. However, a non-English speaking audience may not be able to establish a 
relationship between the slogan and the image, and the effect triggered by this relationship is lost for a non-English speaker, who may not understand the words present in the text. In global campaigns such as those for Absolut Vodka, Donna Karan perfume Delicious or 212 perfume by Carolina Herrera, one common strategy consists of reducing the verbal elements to the minimum, while preserving the same textual components.
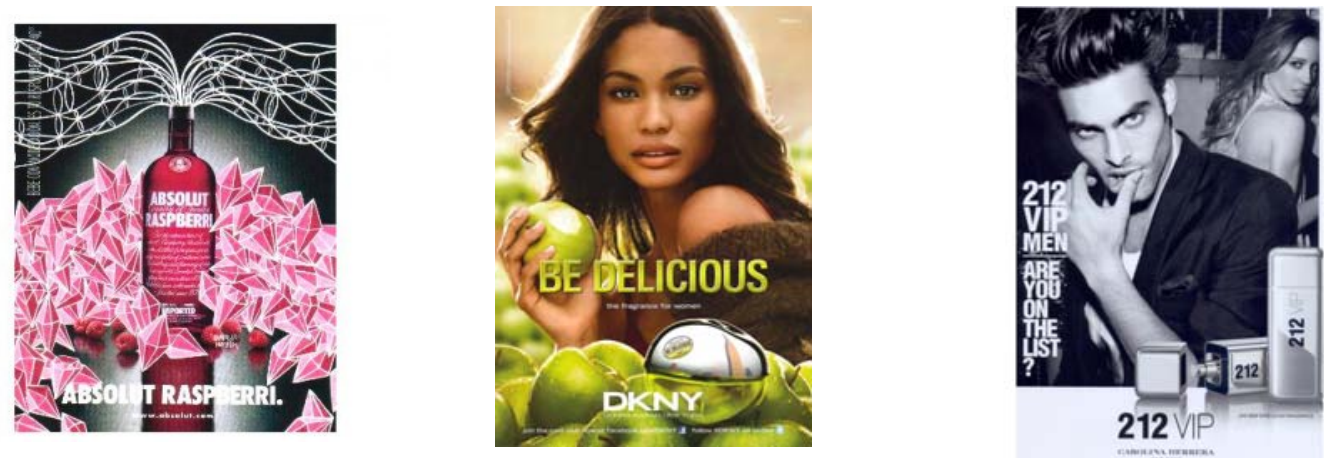

Figure 1. Global campaigns, global ads, non translation.

Although very often the words employed are quite accessible or familiar to international receptors for its simplicity, it is also true that lack of translation, nontranslation, impedes audiences to grasp the full meaning of the campaign. In the first of the advertisements in Figure 1, the Absolut Vodka one for a Spanish magazine $^{3}$, the predominant red berry colour relates the flavour of the vodka to the slogan, which is left in English, while the perpendicular-aligned text indicates in Spanish that alcoholic drinks should be consumed with moderation, complying with legal norms in Spain. In this case it is evident that the institutional norms of the target culture oblige to include the legal prescription in the target language, an unequivocal signal of localization. The two printed advertisements for perfumes also show untranslated texts in English, the language for international campaigns in global marketing campaigns like these ones. The use of English in these examples also arises from the intention to internationalize the product at stake, adding elements appealing the younger sectors of the market.

In the Donna Karan New York advertisement (Allure, April 2011), the campaign is built upon the symbiosis between the product, the woman and the fruit shown in the text; most particularly, there is some parallelism between how delicious the fragrance, the girl and the apple she is eating are. Visually, all the elements invite the target user to try the fruit and above all the perfume, while enjoying the

$3 \quad<$ <ttp://adfactory.ecrater.com/p/3923287/absolut-raspberri-vodka-magazine-ad\#> [20/03/2016]. 
suggestiveness of the female models which are portrayed in the several advertisements. Language turns out to be a secondary element and there is no need to translate it. Even though the verb "Be" may not be familiar to everyone, the term "Delicious" is likely to become meaningful, given its cohesive relationship with the other visual elements.

Likewise, the third advertisement includes a slogan which is left untranslated in English: "Are you on the list?" ${ }^{4}$. As in the previous example, the meaning is created when the right connections between the product and the textual elements are established. In this sense, the perfume brand name is 212 VIP marketed by Carolina Herrera, a designer brand associated with the city of New York and its cosmopolitan culture, and whose main concept consists of sending a clear message to target consumers: "if you use the perfume, you will become a VIP, so you will be on the list, and therefore you will be allowed in parties and other events, so you'd better use the perfume". Again, this subtle marketing message is quite universal and easy to recognise internationally, so there is no need for translation, as the expected target consumer may be able to understand such a phrase.

In the next example (Figure 2), however, although it also reflects a strategy of global marketing, French is used as a lingua franca instead of English.
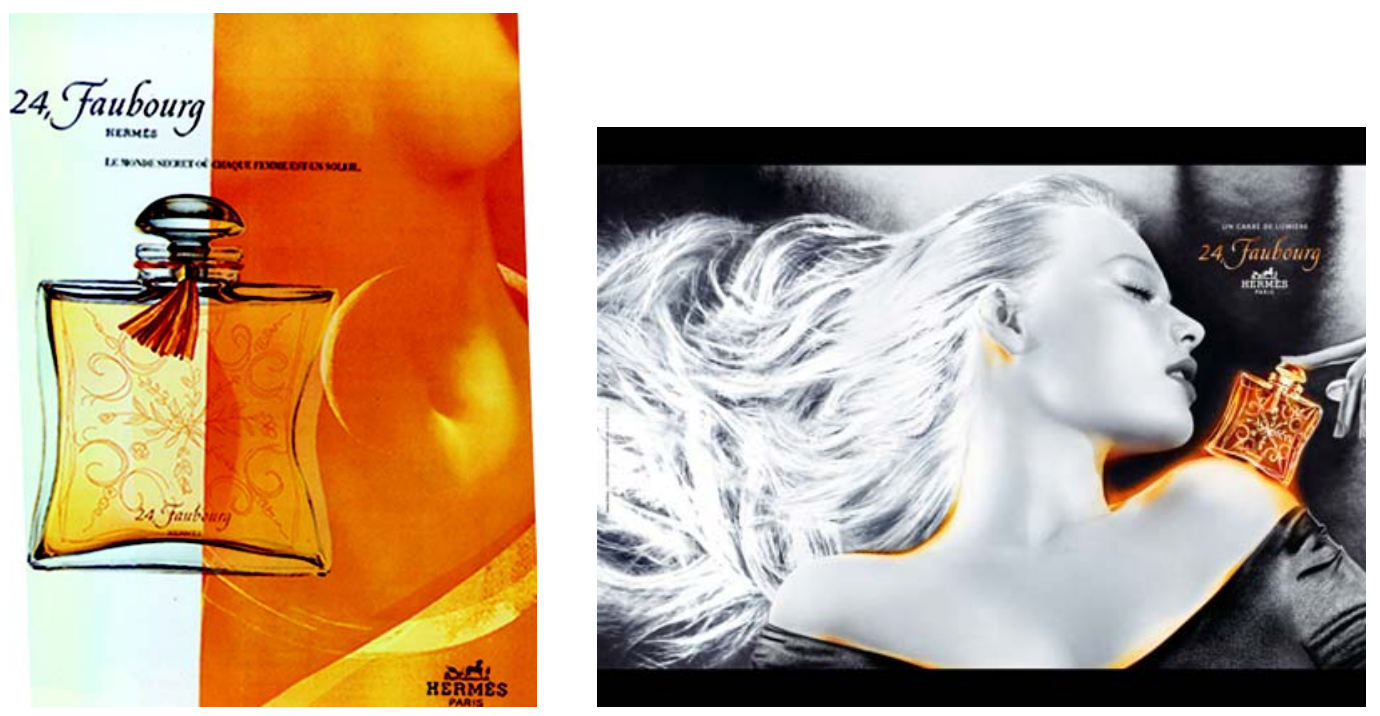

Figure 2. Global campaigns, use of French for fragrances.

This frequently occurs when a company of French origin intends to emphasise its

$4 \quad<$ http://www.thefashionisto.com/jon-kortajarena-for-carolina-herrera-212-vip-fragrancecampaign/> [25/03/2016]. 
prestige in the fields of fashion, and particularly of perfumes and cosmetics for women. The advertisements were published in French in Spanish magazines for a Spanish audience (Marie Claire, May, 1996, and Vogue, Spain, 2006), so the untranslated slogan seems to prevent the receiver from understanding the whole message of the text. However, the effect produced by the icon of the perfume bottle and the brand name, Hermés, a symbol of elegance and prestige, may be enough to trigger the reaction intended by the advertiser, evoking glamour and sophistication.

As we have above-mentioned, institutional norms, attached to particular contexts and systems, have a direct effect on language policies as well, as is the case in France with the Law Toubon ${ }^{5}$, enacted in 1994, which has served to protect the use of the French language opposing the invasion of English expressions in different social areas, including administrative documentation and promotional material. This Law has had immediate effects on advertising, ensuring that, whenever a slogan or tagline appears in another language rather than French, this has to be translated in French as well. Figures 3 and 4 present a few examples:

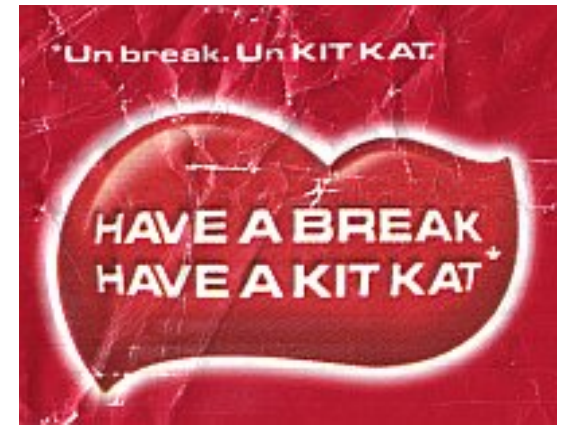

Figure 3. Application of Toubon Law .

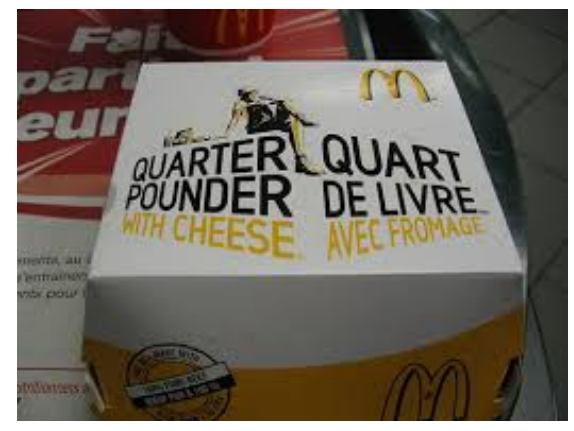

Figure 4. Application of Toubon Law ${ }^{7}$.

However, the fact that textual material is translated into French does not ensure that cultural values and traditions associated to products are also transmitted or imported into the target culture. This is exemplified by the Kit Kat "Take a break" campaign, as De Mooij (2013, p. 72) explains, which is a concept based on the tea break, common in some cultures but not in others. Therefore, the use of a linguistic equivalent may be part of the legal requirement in some contexts, but the cultural inscription of the concept or cultural reference is something more complex to attain

<http://www.culturecommunication.gouv.fr/Politiques-ministerielles/Langue-francaise-etlangues-de-France/Politiques-de-la-langue/20-ans-de-la-loi-Toubon> [29/09/2015].

$6 \quad<$ http://serendipity.lascribe.net/odds-ends/2004/07/minimalistkitkat/index.html\%3Flp_lang_view=en.html> [20/09/2015].

7 <http://lafraussie.blogspot.com.es/2011_11_01_archive.html> [20/09/2015]. 
(Guidère, 2001).

The examples above show that non-translation is one of the main strategies when the marketing campaign is a global one. Costs and efforts are reduced and the campaign is devised from a global point of view "as if the entire world (or major regions of it) were a single entity" (Levitt, 1983, p. 92-93). Other well-known international brands such as Levi's or Harley Davidson provide examples in magazines or on television, where the power of music is largely exploited as a global element. The "Born to Harley Davidson" commercial ${ }^{8}$ limits the verbal elements to the final slogan that gives name to the campaign, without diminishing the value of the storyline. The expression "Born to..." emphasizes the idea that the newly-born baby that appears on screen already carries the Harley Davidson bubbling tune in his genes, as this sound is the remedy to make him fall asleep. Sound effects compensate the lack of textual material, contributing to reinforcing the legend of Harley Davidson motorbikes. Thus, it is a global campaign with global content and universally-recognised elements, such as the idea of transmitting the values of the brand from one generation to another.

Another strategy belonging to the sphere of globalization is based on using the same image and concept in most markets, while translating the headline and the body copy, keeping some text untranslated. This represents a mixed combination of both a global approach as regards the non-verbal elements and the message, and a local approach in terms of language adaptation. The translator plays an active role making the source-language text understandable in the target language, in the light of the marketing campaign, since translating advertising is not only about communicating a product values, but also about communicating the values of the brand and the values of a culture, or providing information about the price, the usage or the services offered. Examples often include the presence of worldwiderecognized celebrities or other symbols.

Nowadays, partnership between celebrities and brands or products stands out as one of the most successful allies to marketing. A well-known person is chosen to create a partnership with a brand or a product, so that associations are naturally established between the values the person represents and the values the brand or product is reputed for. Globalization demands the choice of an international referential sports leader, an actor or an actress, or a leader of a different kind, who embodies the culture of the company, product or brand. Translation plays a fundamental role in transmitting those values, manipulating textual material if needed, in order to fully communicate what is the essence of the campaign. 
We find this strategy in many websites of multinational companies, since the Web has become one of the best instruments to generate and consolidate a global market but allowing local adaptations, at least in principle. The global decisions made within the framework of the marketing campaign give rise to an internationalised website, containing common elements, a similar structure and a platform which allows technical adaptations to the target culture, and finally a localized version of the website is provided. Thus, the principle "Think globally, act locally" becomes real, although De Mooij claims it to be "a paradox", given that "thinking and behaviour are equally affected by culture" (2013, p. 2).

A recent Seiko campaign was based on the partnership with tennis champion Novak Djokovic, who added his own principles and qualities to the brand values, like "being one step ahead of the rest" and "being number one" in the world ranking. The Seiko website ${ }^{9}$ offers the possibility to access the different watch collections choosing the "Global site", in English, or the site from the user's region, localized into the target language of the user. These sites, accessed at from the Seiko general website with their own local domain, combine translated and untranslated promotional material, since not all the different components are localized. Text at toolbars, slogans of each of the Seiko collections and the copy of each website are translated into the target language; on the contrary, streamed videos, part of a microsite called Seiko TV, are not translated, but kept in English, as for example the television commercial featuring Djokovic as Seiko Ambassador, to promote the Seiko Astron GPS Solar watch. High quality visuals and a suggestive music accompany the tennis player's actions and some of the phrases he utters. However, in general, verbal material is reduced to the minimum, including some text being pronounced by an off-voice and a few expressions written on screen. Moreover, the audiovisual text is adapted to the medium norms; in this case it is intended for television platforms, with an average duration of thirty seconds, which has been standardised for this medium, although it can be found as well in the Seiko microsite for Seiko television. One comment to be made concerning translation is that, although Djokovic and what he embodies are sufficiently known, the rendering of the verbal text, both orally and written on screen, in English only prevents part of the target audience from fully appreciating the concept which underlies the campaign ${ }^{10}$ :

- Connect with time. Anywhere in the world. Harness the power of GPS. The world's first GPS solar watch. Astron. From Seiko. Dedicated to perfection.

All the statements can be replicated and assigned to both the Seiko GPS solar watch

\footnotetext{
9 <http://www.seikowatches.com/> [20/09/2015].

10 <http://www.seikowatches.com/tv/index.html> [20/09/2015].
} 
and Djokovic, making them both global elements, with some shared features associated to them. Unlike the television commercial, the rest of promotional material for the Seiko watches in the international websites has been localized, as can be seen in the Spanish version for the Latin American site (Figure 5) and in the Italian version for Italy (Figure 6).

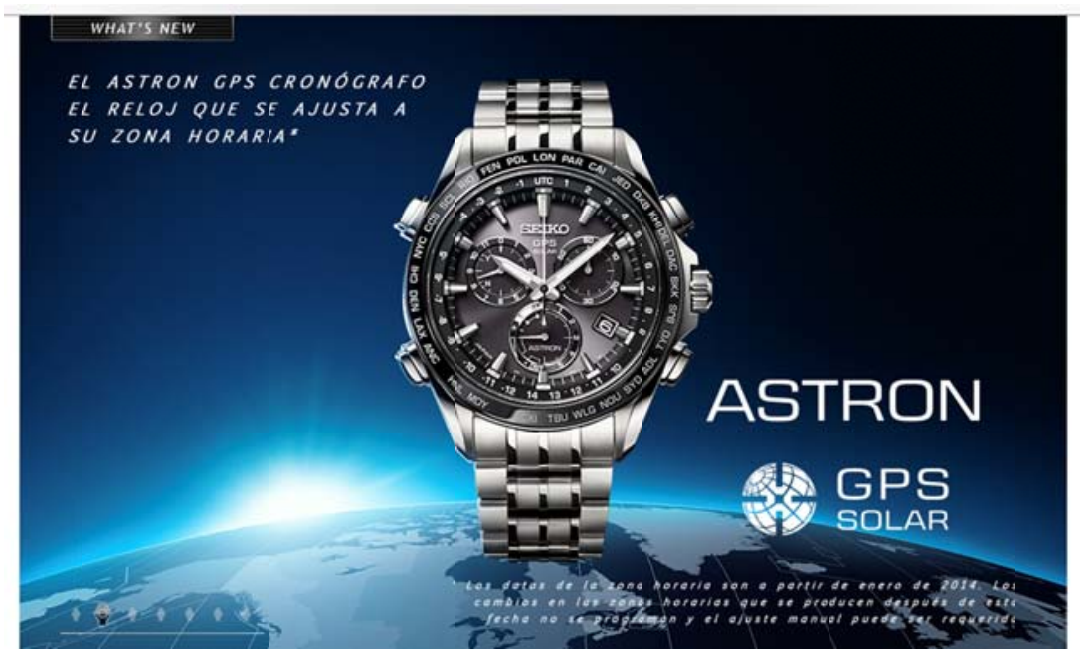

Figure 5. Seiko Astron. Spanish website. ${ }^{11}$

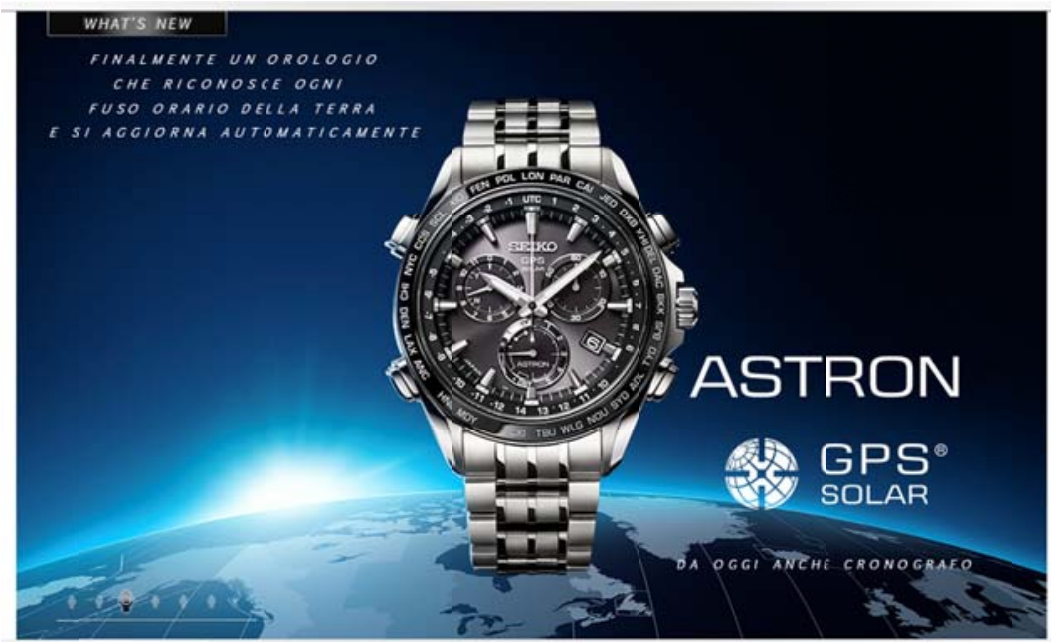

Figure 6. Seiko Astron. Italian website. ${ }^{12}$

\footnotetext{
11 <http://www.seiko-latinamerica.com/> [20/09/2015].

12 <http://www.seiko.it/> [20/09/2015].
} 
Advertising becomes then an instrument helping to build up the identity of the brand and the product, far from any specific culture-based or context-bound orientation, in an attempt at crossing borders and position the product above all national, regional or local coordinates. Similarly to Seiko, other global brands like Tommy Hilfiger, Lancôme or L'Oréal cosmetics employ celebrities that are also recognisable and prestigious in many contexts, and that contribute with some positive values which are worth relating to the product or brand: for example, Rafael Nadal is the latest ambassador for Tommy Hilfiger underwear ${ }^{13}$; Julia Roberts or Kate Winslet, for Lancôme $\operatorname{cosmetics}^{14}$, and Jane Fonda, promoting some ageperfection products for L'Oréal ${ }^{15}$. Each of them provides a set of values and behaviour of interest for the identity of the brand or product, by means of their physical presence on screen or their voice, which can be heard in the videos, as in the L'Oréal television commercial.

A convenient ally to globalization efforts is the so-called "media mix", which facilitates the combination of different media in order to maximise the results in terms of exposure and efficiency, and at the same time allowing the translated or localized versions of the marketing campaign for diverse media such as the Web, television or printed ones. The television is being exploited as a fundamental medium to launch an international campaign given its far-reaching scope and the creative potentiality of the medium, particularly taking advantage of music and its filmic nature. Traditionally, music has been regarded as one of the most effective ways of imposing a common culture, as great hits from previous decades or contemporary ones are (re-)used to attract the spectator's attention. The combination of different media leads to a higher degree of success of advertising efforts for various reasons: firstly, online ads support the effectiveness of television commercials; secondly, television advertisements can be part of the online promotional campaign, and finally it can be claimed that the higher the degree of exposure time, the better. Generally, coherence between the advertising material in the various media is required.

Despite this, the Web has gradually turned out to be a medium of great interest for companies and users. In the case of our study, we have observed that translation, particularly for the Web, facilitates the interchangeability of content, actions, values and products in general. As Cronin (2013, p. 21) puts it:

\footnotetext{
13 <http://global.tommy.com/int/en/collections/start/16\#> [20/09/2015].

14 <http://www2.lancome.com/index.aspx> [20/09/2015].

15 <http://www.loreal-paris.es/portavoz/jane-fonda.aspx $>$ and

$<$ https://www.youtube.com/watch?v=ktATOg-7WkQ> [20/09/2015].
} 
Translation, in this representation, is what makes globalization a reality. It partakes of the culture of fluid extensivity. It allows the channels of global exchange to keep on flowing so that, if nothing else, the Starbuck's customers, wherever they are, know what to order and the staff know what to give them.

\section{Local products want to become international}

A different scenario is created when local companies take the decision to use bilingual or multilingual promotional material to publicise their products, with the sound aspiration to increase their market reach and to position their brands and products in a more prestigious or higher level. Their modest marketing campaigns often start with publishing printed material, much more affordable than other media, to lately invest in websites which offer versions in various languages. In the last few years the reduction of tariff rates and the incentives to stimulate local and regional economic activities have entailed a parallel growth of communication needs and an interest in further internationalization. Within this paradigm, local products, often related to the food, culture or tourism sectors, are the main object of marketing campaigns aiming at boosting sale figures or numbers of users.

An example of these is the Rey Silo cheese, a variety of cheese from the Principality of Asturias, a region in northern Spain, which is locally produced in the small town of Pravia, which boasts about its artisan cheese making processes. Proud of tradition, the product name recalls the medieval times when Asturias was a Kingdom and Pravia was the seat of the royal court in the 8th century. Thus, all messaging revolves around the historical background of Rey Silo cheese, whose production dates back to the times when the Asturian King Silo used to send appreciated local products to the Emperor Charlemagne, including this type of cheese. This emphasis on linking history with the quality of the cheese is present throughout the advertising material of the brand Rey Silo ${ }^{16}$.

Apart from other types of material to internationalize this brand, like labelling, leaflets and brochures, or audiovisual documentaries, it is of particular interest to analyse the website, as it is likely to be the showcase which target consumers of different kind may visit. The Rey Silo website has a quite simple structure and it reinforces the colours which are emblematic for the brand: a pale yellowish tone resembling that of the cheese, an apple-coloured green evoking the Asturian fields and the white background, with some brown and greyish lettering for headlines and keywords. The simplicity of the site equals the efficiency as regards the amount of

16

<http://www.reysilo.es/> [20/09/2015]. 
information: a few short sections can be accessed from the links at the superior toolbar and below several news items and videos can be found. In spite of this, the website presents some serious flaws such as broken links in sections like "Blog" or "Contact", which can be dissuasive, or the unfulfilled promise to find a version in German, which comes up in Spanish when clicked on.

The aspiration to bring the attention of international users to the website and thus of potential consumers of the Rey Silo cheese is reflected in the possibilities of language choice offered at the upper right side of the page, where the user can choose among "Castellano, English, Deutsch and Neerlandés". Therefore, a preliminary decision has been made as to which users are the target for the company's advertising campaign and thus as to which languages should be chosen. First of all, aligned with the recommendations of usability experts, the reference to each language button is made in the language in question "Castellano" in Spanish, "English" in English and "Deutsch" in German), with the exception of "Neerlandés", which is written in Spanish. In order to better invite the user to click on the link to the translated version in Dutch, the "Nederlands" term, that is, in the language of the target, would have been a more coherent option for the menu bar, as users always prefer using websites in their own language.

Another question that arises concerns this language choice in particular, while French would have been a more common option among Spanish websites when expanding commercial activities or exporting products, selecting Dutch may seem intriguingly odd. Certainly, both Germany and Holland are large producers and consumers of cheese, but likewise is France. A hypothesis to account for the Dutch alternative could be that, due to opportunity factors, the company may have required to localize the website to Dutch in order to open a new market or to present the Rey Silo cheese varieties in international market fairs in this languagespeaking areas.

Localization is not only about linguistic transfer but, as Esselink put it (2003, p. 4), "In a nutshell, localization revolves around combining language and technology to produce a product that can cross cultural and language barriers. No more, no less". Therefore, the Rey Silo sections offer various examples of localized content, as in the section "La leche", where there is a description of how the milk to produce the brand's cheese is obtained from Asturian cows, grazing near the place of origin of the cheese. However, there is certain divergence between the data given in the Spanish, the English and the Dutch texts:

- A poca distancia de Pravia se encuentra el pueblo de Oviñana, en el vecino 
concejo de Cudillero, donde María Teresa García atienden ${ }^{17}$ su ganadería de vacas lecheras ${ }^{18}$.

- A short distance from Pravia, in the small village of Oviñana, Cudillero, devote themselves to their dairy cattle ${ }^{19}$.

- Op loopafstand van Pravia ligt het dorp Otero, in de naburige gemeente Salas, waar Nieves y Tino hun melkvee houden ${ }^{20}$.

A brief insight into these three fragments clearly shows that in the Spanish and Dutch texts a reference to the cattle breeders is significant to reinforce the value of domestic and local production from the green meadows of Asturias and the prestige of dairy products from the region, while the English translator does not specify the names of the cattle breeders (the text, like the Spanish one, contains some language mistakes). Interestingly, both the name of the villages and the cattle owners differ in the case of the Spanish and the Dutch versions, which brings up the question of whether the milk chosen for the Rey Silo cheese comes from different locations when the product is intended for one country or another, or whether the texts are uploaded at different periods of time. In the case of websites, it is quite frequent to upload content material for a specific event at a particular date in one language, and other content elements in other languages for events taking place at different dates. This may be the explanation for this textual divergence as far as proper names or references are concerned.

One of the challenges of internationalizing local products is the principle of relevance (Sperber and Wilson, 1995), as culture-bound content deserves some thought about whether it is relevant for target audiences or not, when translating it. Given that translators and localizers should have a thorough knowledge of the cultural codes which are employed in the communication campaign to trigger particular associations, they should be sensitive to the pragmatic effects, and pay careful attention to, of the discursive features of the localized versions. In this sense the section of the Rey Silo cheese website devoted to "El Reino de Asturias en Pravia" ("The Kingdom of Asturias in Pravia") aims at enhancing the prestige of the cheese brand, relating it to the importance of this small town in the Early Middle Ages, by means of a detailed account of historical facts that characterised the royal court in

There is a mistake in the original text, as "atienden" should be "atiende".

<http://www.reysilo.es/2/el-rey-silo/2/la-leche.html> [20/09/2015].

<http://www.reysilo.es/en/2/el-rey-silo/2/la-leche.html> [20/09/2015].

<http://www.reysilo.es/ne/2/el-rey-silo/2/la-leche.html> [20/09/2015]. 
8th century Pravia21:

\section{presentación - el rey silo - el Relino de Asturias en Pravia - noticias - gastronomia - blog • contacta}

\section{EL REINO DE ASTURIAS EN PRAVIA}

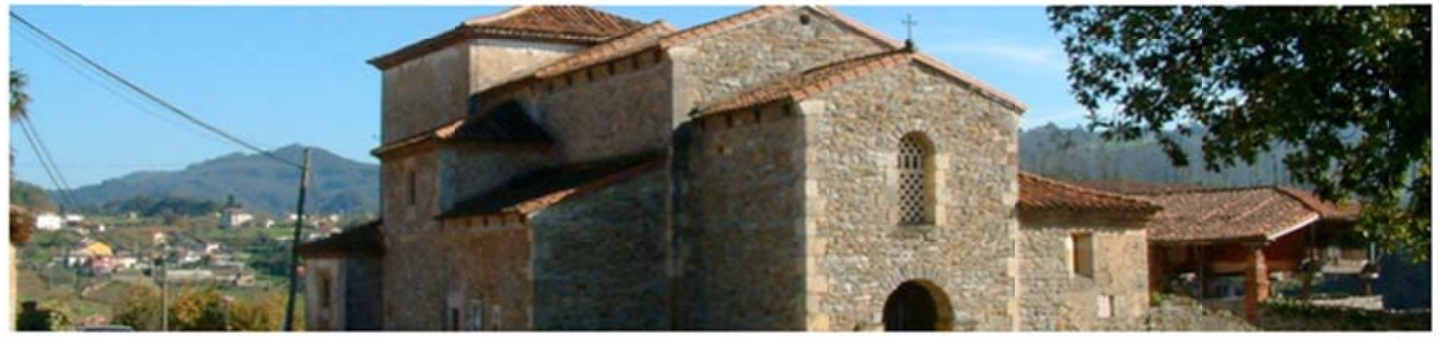

\section{La Corte de Pravia}

En el año 774 , el Rey Silo trasiada a Pravia la pequeña corte del incipiente Reino de Asturias, en donde permanecio hasta el año 792.

El Rey Silo y su esposa, la Reina Adosinda, construyen en Pravia la primera iglesia del prerrománico asturiano, la iglesia de Santianes. El gran Beato de Liébans conoce en Santianes en el ano 785 la carta en la que Elipando, arzobispo de Toledo, le acusa de herejia por defender la divinidad de Cristo, iniciándose asi en Pravia la batalla teológica del Adopcionismo que sacudió la cristiandad y a la que puso fin muchos años después el propio emperador Carlomagno, ante cuya corte Beato de Lićbana acudió en calidad de embajador del Rey Alfonso II El Casto, 10brino de la esposa del Rey Silo, ta reina Adosinda.

Beato de Liebana escribió el libro "Comentarios del Apocalipsis" de San Juan, una recopilación de textos teológicos de los primeros pensadores del cristianismo, a los que el monje liebanés tuvo acceso gracias al apoyo de las sucesivos reyes asturianos. Hoy esos códices, miniados en los mejores Scriptorium de los conventos medievales de toda Europa, se conocen como "Beutos".

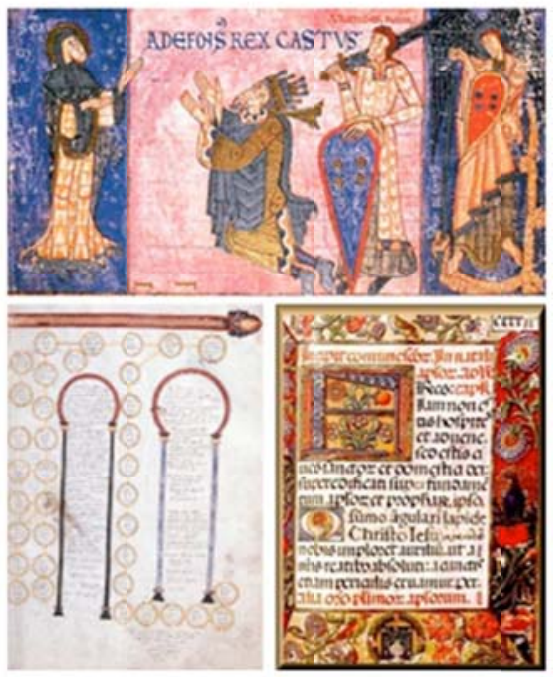

Figure 7. Rey Silo cheese website. Spanish version.

It is worth highlighting the cohesive relationship between the illustrations and the photograph shown on screen and the content displayed in the verbal text, at least in the Spanish version. The medieval illustrations and codex represent scenes with Alphonsus II the Chaste and religious codices, such as the Commentary on the Apocalypse of John by Beatus of Liébana, while the picture refers to the Prerromanesque church of Santianes, mentioned in the second paragraph.

When localising this section into English, the translator has intentionally reduced its content, omitting the details about the visit paid by Beatus of Liébana as ambassador of King Silo, about the kinship relationship of Queen Adosinda and

21 <http://www.reysilo.es/3/el-reino-de-asturias-en-pravia/6/el-reino-de-asturias-en-pravia.html> [20/09/2015]. 
Charlemagne, or about the Commentary on the Apocalypse of John by Beatus of Liébana and its theological and cultural importance at the time. The reason for this exclusion is likely to be that the translator considered these data too specific or irrelevant for the English-speaking target users, who may have access to the website from different international locations, prioritising the principle of relevance over the historical importance of the events that took place in Pravia, the place of origin of Rey Silo cheese. Nevertheless, at the expense of this reduction, there is a lack of verbal content to relate to the non-verbal one, so that the absence of text on Beatus of Liébana's Commentary reveals that the target audience of the English website cannot but infer what the two last pictures are about.

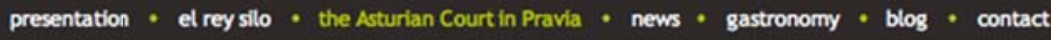

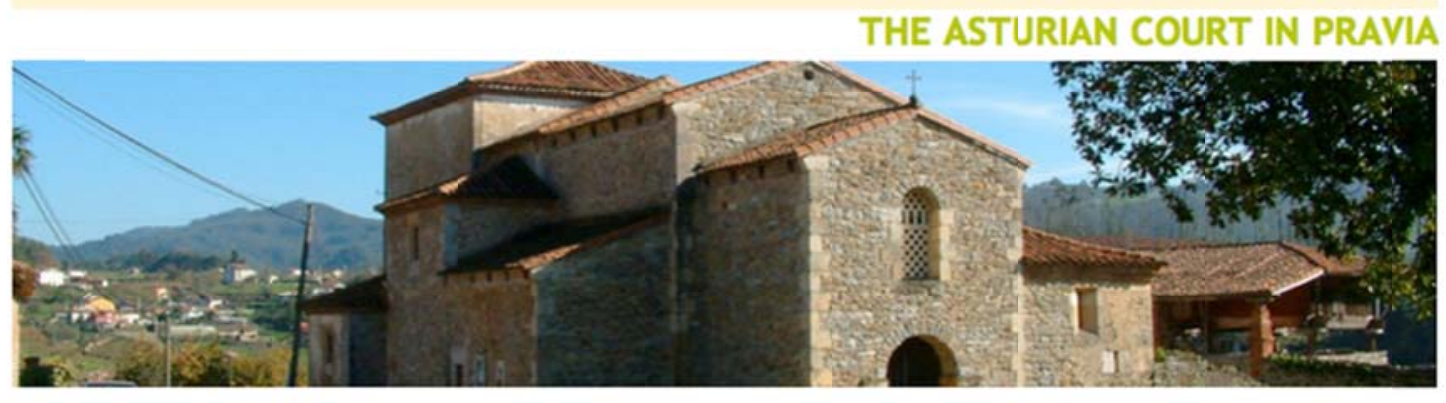

The court of the young Asturian kingdom was moved to Pravia in 774 by the king, Rey Silo, where it remained until 792 .

King Silo and his wife, Queen Adosinda, had the church in Santianes built, the first of the Asturian Pre-Romanesque style. It was there in 785 that the great Beato de Liébana learned through a letter from the Archbishop of Toledo, Elipando, that he was accused of heresy for defending the divinity of Christ. Thus began in Pravia the battle over the theology of Adootionism which would divide Christianity for years and was finally settled later by the Emperor Charlemagne, himself.

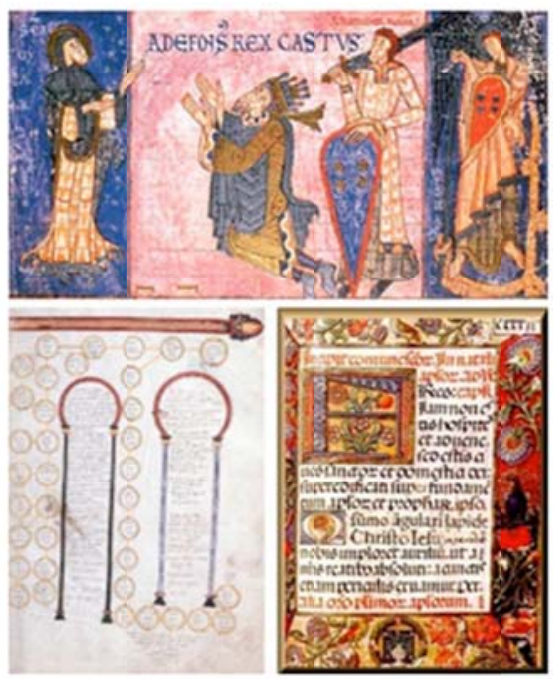

Figure 8. Rey Silo cheese website. English version.

This reduction or deletion strategy, resulting from the application of the principle of relevance by translators, can be commonly found in promotional texts which are rich in historical accounts or culture-specific elements, such as tourism or advertising material, since this kind of information may not be considered appealing 
for advertising purposes or intended for wide audiences, given the different cultural codes that are required to fully understand all the details (Mooij, 2004; Cómitre \& Valverde Zambrana, 2014; Valdés, 2001 and 2004).

\section{Concluding remarks}

The examples included above have pointed out that globalization does not only arise from the economic and communicative principles that rule advertising today, but that it also influences the translating process as well. Advertising translation is bound to the marketing strategy adopted by companies, which may opt for a global approach combined with a local communication strategy, or for an international policy to bring new products to a more global level. In the first alternative, language translation is used to localize the global content of the promotional material, while in the second one translation is an instrument to internationalise the local one. Undoubtedly the use of one global language, mainly English, is time and cost effective and thus is still part of international campaigns of global brands, particularly those targeting certain segments of population, so non-translation and partial translation can be instrumental to perpetuate global elements or, on the contrary, to comply with legal regulations that oblige to use local languages.

Moreover, the partnership between brands or products and celebrities has growingly become a successful strategy, which implicitly imposes some translation decisions as well, and contribute to triggering some associations between the promoted product and the celebrity and to creating symbiotic relationships between them. Concerning the media, the several possibilities of combination facilitate gaining access to global brands and messages, but at the same time spreading local interests and products in a broad sense.

On the other end of economic trends, small and medium companies attempt at positioning their products at international markets, exploiting specific culture-bound themes and characters to preserve local flavour at the time this is conveyed internationally. Translation occupies a prime position in making localization gain ground.

Instead of focusing on tensions between globalization and localization approaches, it would be comparatively more interesting to appreciate the benefits of complementing one with the other, in order to make better decisions to adapt the advertising material to the various media and to the different cultural backgrounds. The access to the Web of larger numbers of people of non-English speaking areas or of users wishing to use their own languages is starting to give rise to the presence of new elements and phenomena, which may bring substantial changes to translation 
in the long term. For example, a field still to explore comprises websites, or parts of them, that have been created in hybrid forms, that is, in English and in a minority or minoritised language, which will challenge the all-powerful global language par excellence, English, or other major languages such as Chinese (Raine, 2010). Likewise, a more varied offer of local products, brands or institutions which place emphasis on locally-bound cultural factors have also appeared on the Web, thus contributing to the further heterogenisation of content and to the visibilisation of diversity. If a local Asturian cheese can find its place on the Web in different languages, it means that it will be available to more potential customers from different parts of the world, hoping to improve the market aspirations of the company.

Although localization is not a new trend in advertising and globalization still seems to occupy a prime position, translation seems to reveal challenges to globalization and to bring diversity to the forefront, as Mooij $(2013$, p. 2) underlines: "Globalization has not produced globally uniform consumers. Although there is a worldwide convergence of technology, media, and financial systems, desires and behaviors of consumers are not converging." Thus, local brands and products want to become both international and local at the same time, requiring localization and translation to overcome any cultural tension and to preserve their local identity in international contexts. Therefore, further studies will be on demand to examine these local-tointernational processes, particularly focusing on the impact and the role of the Internet on them.

\section{About the author}

Cristina Valdés is a full-time lecturer of English Studies at the University of Oviedo (Spain). Her main research has been carried out in the field of advertising translation, website translation/localization, intercultural communication and the reception of the 18th century English translations of Don Quixote. She has participated in several European projects on intercultural communication, language learning, the multilingual web and screen translation. She is the author of La traducción publicitaria: comunicación y cultura (2004) and co-edited with Beverly Adab Key Debates in the Translation of Advertising Material. The Translator 10(2): Special Issue. She has published different papers and contributions to the Handbook of Translation Studies and The Routledge Handbook of Translation Studies. 


\section{Article history}

Paper received: 26th September 2015

Paper received in revised form and accepted for publication: 26th April 2016

\section{References}

Adab, B. \& Valdés, C. (Eds.) (2004). Key Debates in the Translation of Advertising Material. The Translator, 10(2). Special Issue. Manchester: St Jerome Publishing.

Bueno García, A. (2000). Publicidad y traducción. Soria: Monográficos de la Revista Herméneus. Vertere.

Cómitre, I. (2000). Traducción y publicidad. Aproximación a una estrategia traductora (francés-español). Unpublished Doctoral Thesis. Málaga: Universidad de Málaga.

Cómitre, I. \& Valverde Zambrana, J. M. (2014). How to translate culture-specific items: a case study of tourist promotion campaign by Turespaña. Jostrans. The Journal of Specialised Translation, 21, 71-111. <http://www.jostrans.org/issue21/art_comitre.php> [20/04/2016].

Corpas, G., Martínez, A. \& Amaya, C. (Eds.) (2002). En torno a la traducción-adaptación del mensaje publicitario. Málaga: Universidad de Málaga.

Cronin, M. (2013). No Direction Home? Translation and the Limits to Globalization. Intercultural Communication Review, 11, 15-27.

Cruz García, L. (2001). La traducción de textos publicitarios. Los anuncios de productos informáticos. Unpublished Doctoral Thesis. Las Palmas de Gran Canaria: Universidad de Las Palmas de Gran Canaria.

Dávila-Montes, J. (2008). La traducción de la persuasión publicitaria. Lewiston, Nueva York: Edwin Mellen.

Dollerup, C. (2008). Translation in the Global/Local Tension. In W. Ning \& S. Yifeng (Eds.), Translation, Globalization and Localization: A Chinese Perspective (pp. 31-49). Clevedon, UK; Buffalo, NY: Multilingual Matters.

Esselink, B. (2003). The evolution of localization. The Guide from Multilingual Computing and Technology: Localization, 14(5), 47.

Fernández Montes, M. A. (2016). Traducción y globalización. Análisis y perspectivas del fenómeno publicitario (Esp-Alemán-Inglés). Málaga: Comares. 
Fuentes Luque, A. \& Kelly, D. (2000). The Translator as Mediator in Advertising Spanish Products in English-Speaking Markets. In A. Beeby, D. Ensinger \& M. Presas (Eds.), Investigating Translation. Selected papers from the 4th International Congress on Translation, Barcelona, 1998 (pp. 235-242) Barcelona.

Goldman, K. (1992). Professor Levitt Stands by Global Ad Theory. The Wall Street Journal (October 13, 1992), B7.

Guidère, M. (2000). Translating Ads. Paris: Harmattan.

Guidère, M. (2001) Translation Practices in International Advertising. Translation Journal, 5(1), January 2001. <http://translationjournal.net/journal/15advert.htm> [23/04/2016].

Lambert, J. (1994). Ethnolinguistic democracy, translation policy and contemporary world (dis)order. In F. Eguiluz, R. Merino et al. (Eds.), Trasvases culturales. Literatura, cine, traducción (pp. 23-36). Vitoria: Universidad del País Vasco.

Levitt, T. (1983). The Globalization of Markets. Harvard Business Review, 61(3), 92-102.

LISA. (2003). LISA Localization Industry Primer. The Localization Industry Standards Association. $<$ http://www.dynamiclanguage.com/home14/wpcontent/uploads/2014/07/LISA-Localization-Primer.pdf> [20/09/2015].

LISA. (2007). LISA Globalization Industry Primer. The Localization Industry Standards Association. $<$ http://www.dynamiclanguage.com/home14/wpcontent/uploads/2014/07/LISA-Globalization-Primer.pdf> [20/09/2015].

Lorenzo, L. \& Pereira, A. (Eds.) (2005). Traducción subordinada III: traducción y publicidad. Vigo: Universidad de Vigo.

Mooij, M. de (2004). Translating Advertising. Painting the Tip of an Iceberg. In B. Adab \& C. Valdés (Eds.), The Trans/ator, 10(2), 179-198.

Mooij, M. de (2013). Global Marketing and Advertising: Understanding Cultural Paradoxes. Los Angeles, London, New Delhi, Singapore, Washington D C: Sage Publications.

Pedro Ricoy, R. de (2007a). Las estrategias de internacionalización en la traducción publicitaria. Revista de lingüística aplicada y lenguas aplicadas, 2, 5-14.

Pedro Ricoy, R. de (2007b) Internationalization vs. Localization: The Translation of Videogame Advertising. Meta: journal des traducteurs, 52(2), 260-275.

Raine, R. (2010). Minority, languages and translation in Tibet. Minor Translating Major, 2, 35-53.

Schäffner, C. (2000). Translation in the Global Village. Clevedon, Philadelphia and Adelaide: Multilingual Matters. 
Snell-Hornby, M. (1988). Translation Studies: an Integrated Approach. Amsterdam and Philadelphia: John Benjamins.

Snell-Hornby, M. (2000). Communicating in the Global Village: On Language, Translation and Cultural Identity. In C. Schäffner (Ed.), Translation in the Global Village (pp. 11-28). Clevedon, Philadelphia and Adelaide: Multilingual Matters.

Sprung, R. C. (Ed.) (2000). Translating into Success. Cutting-edge strategies for going multilingual in a global age. American Translators Association Scholarly Monograph Series. Vol. XI. Amsterdam/Philadelphia: John Benjamins Publishing Company.

Torresi, I. (2007). Translating the Visual. The Importance of Visual Elements in the Translation of Advertising across Cultures. In K. H. Ryou \& D. Kenny (Eds.), Across Boundaries: International Perspectives on Translation Studies (pp. 38-55). Newcastle: Cambridge Scholars Publishing.

Torresi, I. (2010). Translating Promotional and Advertising Texts. Manchester: St. Jerome.

Toury, G. (1995). Descriptive Translation Studies and Beyond. Amsterdam and Philadelphia: John Benjamins Publishing Company.

Valdés, C. (2001). Las estrategias traductoras de los elementos culturales en los anuncios publicitarios. In A. Barr, M. R. Martín Ruano \& J. Torres del Rey (Eds.), Últimas corrientes teóricas en los estudios de traducción y sus aplicaciones (pp. 811-818). Salamanca: Servicio de Publicaciones de la Universidad de Salamanca. Ediciones Aquilafuente.

Valdés, C. (2004). La traducción publicitaria: comunicación y cultura. La Aldea Global. València: Universitat de València. Castelló de la Plana: Publicacions de la Universitat Jaume I. Barcelona: Universitat Pompeu Fabra. Bellaterra: Universitat Autòmoma de Barcelona. Servei de Publicacions.

Valdés, C. (2008). The localization of promotional discourse on the Internet. In D. Chiaro, C. Heiss \& C. Bucaria (Eds.), Between Text and Image: Updating research in screen translation (pp. 227-40). Amsterdam: John Benjamins.

Vermeer, H. (1989). Skopos and Commission in Translational Action. In A. Chesterman (Ed.), Readings in Trans/ation Theory (pp. 173-187). Helsinki: Oy Finn Lectura Ab.

Vermeer, H. (1992). Is Translation a Linguistic or a Cultural Process? In M. Coulthard (Ed.), Studies in Trans/ation/Estudos in traduçåo, Ilha do Desterro, 28 (pp. 37-49). Florianópolis: Editora Da Ufsc.

Wells, W., Burnett, J. \& Moriarty, S. (1995). (3rd ed.) Advertising. Principles and Practice. New Jersey: Prentice Hall. 